\title{
Physicochemical and Characterization of Nitrogen Fixing Bacteria from Soil Samples Within the Vicinity of Telecommunication Mast (Site No: 000148) Located at Karfi Town Kura Local Government, Kano State
}

\author{
Lawal, I. (iD and Yusuf, I \\ Department of Microbiology, Faculty of Life Sciences, College of Natural and \\ Pharmaceutical Sciences, Bayero University Kano, P.M.B 3011, Kano State- Nigeria. \\ Corresponding author: lawalibrahim646@gmail.com
}

\begin{abstract}
The telecommunication mast associated-radiation is one of the primary factors influencing the way in which microorganisms interact with ecosystem. This study aims to assess the physicochemical and non-symbiotic nitrogen fixing bacteria (NNFB) from soil samples within the vicinity of telecommunication mast located at Karfi town Kura local government Kano state. Soil samples $A, B$, and $C$ were collected within the vicinity of the mast at an interval of 10 meters, 20 meters and 30 meters from the mast respectively and control sample (D) was collected from location *(outside the vicinity of the mast)*. Physicochemical parameters of the soil samples were analyzed, isolation and identification of non-symbiotic nitrogen fixing bacteria were carried out using standard procedures. Samples B showed higher values of $\mathrm{pH}(8.02)$, phosphorus $(23.95 \mathrm{mg} / \mathrm{kg})$, organic carbon $(1.45 \%)$, nitrogen $(0.28 \%)$ and organic matter content $(2.50 \%)$ while control sample (D) showed lower values with $6.24,2.77 \mathrm{mg} / \mathrm{kg}, 0.41 \%, 0.07 \%$ and $0.71 \%$ of $\mathrm{pH}$, phosphorus, organic carbon, nitrogen and organic matter content respectively. However, the moisture content $(0.21 \%)$ of control sample is higher than that of sample $A$ and $B$ with $0.12 \%$ and $0.11 \%$ respectively The mean count of NNFB of the soil samples were $3.20 \pm 0.06,1.80 \pm 0.12$, $1.40 \pm 0.23,1.20 \pm 0.20$ for sample $B, C, A$ and $D$ respectively. Total of 14 isolates of the species Azomonas agilis 1(7.14\%), Azotomonas insolita 1(7.14\%), Bacillus megaterium 2(14.28 \%), Bacillus azotoformans 1(7.14\%), Bacillus mycoides 3(21.42\%), Enterobacter cloacae 3(21.42\%), and Klebsiella pneumonia 3(21.42\%) were obtained. This indicates that the electromagnetic radiation from the mast has no effect on soil physicochemical parameters as well as non symbiotic nitrogen fixing bacteria proliferation.

Key words: Non symbiotic Bacteria, telecommunication mast.
\end{abstract}

\section{INTRODUCTION}

Soil fertility is determined by both its physical properties and its nutrients composition. Lack of agricultural inputs, overgrazing and continuous cultivation practice, coupled with environmental factors aggravates the degradation of soil physicochemical properties (Habtamu, 2011). The introduction of wireless telecommunication in the 1990's caused a massive increase in electromagnetic pollution in cities of Nigeria (Balmori, 2016). Multiple sources of mobile communication result in chronic exposure of a significant part of life to microwaves at non-thermal levels (Belyaev, 2005; Sienkiewicz, 2017). The effects of electromagnetic radiation on the biological functions of living organisms represent an emerging area of interest with respect to environmental influences on living organisms
(Belbe and Tofana, 2010; Belyaev, 2011; Saleh et al., 2018; Yari et al., 2019).

Biological fixation of atmospheric nitrogen has been estimated to have fixed about 70\% (175 million metric tons) of all nitrogen on the earth per year (Onyeze et al., 2013). This essential transformation of atmospheric nitrogen is mediated by bacteria (Tai et al., 2013). A number of non-symbiotic nitrogen fixing bacteria have been isolated from different environment including bacteria of the genus Azotobacter (Ahmed et al., 2013; Ibrahim et al., 2014), Bacillus (Onyeze et al., 2013; Emmyrafedziawati and Stella, 2018), Enterobacter (Ibrahim et al., 2014). The possibility of an effect evoked by electromagnetic radiation on bacterial distribution and other parameters like soil nutrients deserves special attention in light of 
the problem that chemical fertilizers poses to The main objective of this investigation is to assess the Physicochemical and characterize nitrogen fixing bacteria from soil samples within the vicinity of telecommunication mast located at Karfi town Kura local government Kano State, Nigeria.

\section{METHODOLOGY}

\section{Study Area}

The sampling area was Karfi in Kura Local Government Area of Kano state, Nigeria which is located along $11^{\circ} 4559^{\prime} \mathrm{N}$ and $09^{\circ} 1551^{\prime} \mathrm{E}$ coordinates. The sampling points were $A\left(\mathrm{~N} 11^{\circ}\right.$, 48. 886', $\left.008^{\circ}, 29.170^{\prime} \mathrm{E}\right), \mathrm{B}\left(\mathrm{N} \mathrm{11^{ \circ }}, 48.889^{\prime}\right.$, $\left.008^{\circ}, 29.175^{\prime} \mathrm{E}\right)$ and $\mathrm{C}\left(\mathrm{N} 11^{\circ}, 48.891^{\prime}, 008^{\circ}\right.$, 29. 182' E) within the vicinity of the telecommunication mast $\left(\mathrm{N} \mathrm{11^{ \circ }}, 48.877^{\prime}, 008^{\circ}\right.$,

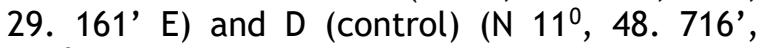
$008^{\circ}, 29.207^{\prime}$ E) 700 meters away from the mast.

\section{Sample Collection}

Three soil samples labeled A, B, C were collected at the interval of 10,20 and 30 meters away from the mast. The mast has attachments of antennas, receivers and transmitters which emit electromagnetic radiation. The control sample $D$ was collected from agricultural soil outside the vicinity of the mast (700 meters away from the mast). In each of the sample sites, soil sample was collected at $20 \mathrm{~cm}$ depth of the soil using soil auger in sterile polythene bags. One hundred and fifty grams (150g) was obtained at each sampling point and transported to the microbiology laboratory Bayero University Kano for analyses. Ten grams from each soil sample was used for microbiological analyses and hundred grams was used for the determination of $\mathrm{pH}$, phosphorus, organic matter, organic carbon, nitrogen and moisture contents.

Determination of Soil Particle Size Distribution

Particle size distribution was determined using Bouyouncos hydrometer method as described by Gee and Or (2002). The sand, silt and clay fraction were determined using equation 1, 2 and 3 . The percentage obtained and the USDA textural triangle was used to classify the soil.

$$
\begin{aligned}
& \text { Sand }=100-2\left[\left(\mathrm{H}_{1}-\mathrm{B}_{1}\right)+0.36\left(\mathrm{~T}_{1}-20\right)\right] \text {. } \\
& \text { Clay }=2\left(\mathrm{H}_{2}-\mathrm{B}_{2}\right)+0.36\left(\mathrm{~T}_{2}-20\right)
\end{aligned}
$$

Where:

$\mathrm{H}_{1}=$ Hydrometer Reading at 40 seconds after stirring

$\mathrm{H}_{2}=$ Hydrometer Reading at 3 hours after stirring

$\mathrm{B}_{1}=$ Hydrometer Reading at 40 seconds after stirring for the blank agriculture (Adebayo et al., 2014).

$\mathrm{B}_{2}=$ Hydrometer Reading at 3 hours after stirring the blank

$\mathrm{T}_{1}=$ Temperature Reading at 40 seconds after stirring

$\mathrm{T}_{2}=$ Temperature Reading 3 hours after stirring the blank

\section{Determination of Phosphorus}

Soil samples were prepared and caliberated according to the method of Vummiti (2015) using microwave plasma atomic emission spectrophotometer (MP-AES) (Agilent 4200, India). A $0.005 \mathrm{M}$ diethylene triamine penta acetic acid (DTPA) and $1 \mathrm{M}$ ammonium acetate solutions were used as the extractants. Ten grams of soil samples was weighed into a polyethylene shaking bottle and $20 \mathrm{ml}$ of DTPA reagent was added. After shaking for 120 minutes, the samples were filtered using whatmann filter paper. Twenty five millilitre of $1 \mathrm{M}$ ammonium acetate solution was added to $5 \mathrm{~g}$ of the samples in in another polyethylene shaking bottle and was shaken for 30 minutes after which the samples were filtered through whatmann filter paper. The physicochemical parameters of the filtered samples were analysed using NIRS (near infra red system: NIRS DS 2500) analyser designed by FOSS.

\section{Determination of Soil Moisture Content}

Empty moisture can was weighed as $\left(\mathrm{W}_{1}\right)$ and five (5) grams of soil sample was added to the moisture can with tight fitting lid and reweighed as $\left(\mathrm{W}_{2}\right)$. The moisture can containing the soil sample was then dried in an oven at $105^{\circ} \mathrm{C}$ for $24 \mathrm{hrs}$ after which the whole content was removed and put into desiccator to cool. After cooling, the contents were re-weighed as $\left(\mathrm{W}_{3}\right)$ (Eno et al., 2009).

Moisture content (\%) was calculated according to the formula below;

Moisture content $(\%)=\frac{W_{2}-W_{3}}{W_{3}-W_{1}} \times 100$

Where: $W_{1}=$ Empty moisture can

$\mathrm{W}_{2}=$ Empty moisture can and $5 \mathrm{~g}$ of the normal soil sample

$\mathrm{W}_{3}$ =Empty moisture can and $5 \mathrm{~g}$ of the soil sample

\section{Determination of Soil Organic Carbon}

A $0.5 \mathrm{~g}$ of soil sample was weighed into $250 \mathrm{ml}$ conical flask and $10 \mathrm{ml}$ of $1 \mathrm{~N} \mathrm{~K}_{2} \mathrm{Cr}_{2} \mathrm{O}_{7}$ solution was pipetted accurately into the flask and swirled gently to disperse the soil. A $20 \mathrm{ml}$ conc. $\mathrm{H}_{2} \mathrm{SO}_{4}$ was added into the flask and the flask was swirled gently until soil and reagents were mixed, and then swirled more vigorously for one minute. 
The flask was allowed to stand for30mins for oxidation to complete and $100 \mathrm{ml}$ of distilled water was added. Three (3) drops of phenantholine indicator was added and the content was titrated against standard $0.5 \mathrm{~N}$ ferrous sulphate solution to obtain an end point. A blank was prepared with same treatment to that of the sample (Eno et al., 2009).

Organic carbon (\%) content of the soil sample was calculated according to the formula below:

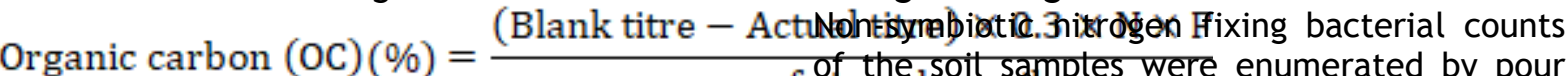

$A=$ Volume of the sample reuired for titration of the sample,

$B=$ Volume of sample required for titration of blank,

$\mathrm{N}=$ Normality of $\mathrm{HCl}$,

$0.014=$ Miliequivalent weight of nitrogen .

$\mathrm{Ad}=$ Aliquot taken

$W=$ Weight of the sample

$\mathrm{VD}=$ Volume of the digest

Enumeration and Isolation of Non-Symbiotic Nitrogen Fixing Bacteria gram of of the solit samples were enumerated by pour

Where:

$\mathrm{F}=$ Correction factor $=1.33$

$\mathrm{N}=$ Normality of solution used

\section{Determination of Soil pH}

Ten grams $(10 \mathrm{~g})$ of air-dried soil (passed through $2-\mathrm{mm}$ sieve) was weighed into a $50-\mathrm{ml}$ beaker and $25 \mathrm{ml}$ of sterile distilled water was added. The suspension was stirred several times for 30 minutes with a glass rod. The soil suspension was then allowed to stand for 15 mins (allowing most of the suspension clay to settle out from the suspension). Electrodes of the $\mathrm{pH}$ meter (Cyberscan pH 510, Singapore) was inserted into the partly settled suspension and the $\mathrm{pH}$ reading was noted and recorded (Eno et al., 2009).

Determination of Total Nitrogen

Kjeldhal method as described by Eno et al. (2009) was used to determine the the total nitrogen in soil samples. One gram of each soil sample was taken in individual Kjeldhal flask. Then 2 grams of a catalyst (mixture of $\mathrm{Na}_{2} \mathrm{SO}_{4}$, $\mathrm{CuSO}_{4}$ and Selenium powder in 100:10:1 proportion) and 30 mlof $\mathrm{H}_{2} \mathrm{SO}_{4}$ were added in each flask and heated gently until frothing ceased. After the formation of clear solution in each flask, the digestion was continued for 30 minutes. Then $50 \mathrm{ml}$ of distilled water and $30 \mathrm{ml}$ of $40 \% \mathrm{NaOH}$ were added. After cooling, the mixtures were then transferred to a Kjeldhal distillation flask. Ten $(10 \mathrm{ml})$ millilitres of boric acid solution and two drops of indicator (Bromocresol green and Methyl red) solutions were taken in three different volumetric flasks. Furthermore, the distillation flask were heated for 30 minutes and the distillate of each sample was collected in their saperate flasks and titrated against $0.025 \mathrm{~N} \mathrm{HCl}$. The percentage of nitrogen was calculated as

$$
\text { \%Nitrogen }=\frac{A-B \times N \times 0.014 \times V D}{A d \times W} \times 10 \begin{aligned}
& \text { she } P<0.05 \text { was considered statistically } \\
& \text { significant }
\end{aligned}
$$

Where:
2018). Ten grams of each soil sample was weighed and added to $90 \mathrm{ml}$ sterilized distilled water. The mixture was shaken for $1 \mathrm{hr}$ in orbital shaker (Agitator 711). Ten-fold dilutions of the soil samples were made using sterilized distilled water. The nitrogen free medium (Beijerickia medium) was prepared by dissolving $20.0 \mathrm{~g}$ Sucrose, $0.8 \mathrm{~g} \quad \mathrm{KH}_{2} \mathrm{PO}_{4}, 0.2 \mathrm{~g}$ $\mathrm{K}_{2} \mathrm{HPO}_{4}, 0.5 \mathrm{~g} \mathrm{MgSO} .7 \mathrm{H}_{2} \mathrm{O}, 0.1 \mathrm{~g} \mathrm{FeCl}, 0.005 \mathrm{~g}$ molybdenum in 1 litre of distilled water. The medium was set to $\mathrm{pH} 6.5$ using $5 \% \mathrm{NaOH}$ and $\mathrm{pH}$ meter and was sterilized by autoclaving at $121^{\circ} \mathrm{C}$ for 15 minutes. One $(1 \mathrm{ml})$ of $10^{-4}, 10^{-5}$, $10^{-6}$ dilutions were poured onto the plates followed by the sterilized molten nitrogen free medium. The inoculated petri dishes were inverted and incubated for 5 days at $37^{\circ} \mathrm{C}$. Nonsymbiotic nitrogen fixing bacteria were expressed as colony forming units per gram of the soil $(\mathrm{cfu} / \mathrm{g})$. Pure cultures of the isolates were obtained by sub-culturing the primary isolates.

\section{Identification of the Isolates}

The isolates obtained were identified using gram reaction, morphological and biochemical characteristics. The biochemical tests; urease, indole, methyl red, vorgues-prokauer, nitrate reduction, starch hydrolysis, citrate utilization, oxidase, catalase and sugar fermentation tests of the bacterial isolates were carried out according to the method described by Cheesbrough (2006).

\section{Statistical Analysis}

All data were analyzed using the statistical package SPSS (Version 20) and Microsoft Excel 2013. Descriptive statistics were carried out to determine the mean non-symbiotic bacterial counts and expressed as Mean \pm SD. One way Analysis of Variance and was used to show 


\section{RESULTS}

Physicochemical properties of soil samples found near telecommunication mast

The physicochemical properties of soil samples found near telecommunication mast are depicted in Table 1 and Figure 1. The parameters analyzed are $\mathrm{pH}$, phosphorus, organic matter, organic carbon, nitrogen and moisture content. From the results, it was observed that the $\mathrm{pH}$ of the control soil (6.24) sample was the least compared to the $\mathrm{pH}$ values of $6.48,8.02$ and 7.80 observed in 10,20 and 30 meters near the telecommunication mast. The phosphorus levels ranged between
$2.77 \mathrm{mg} / \mathrm{kg}$ and $23.95 \mathrm{mg} / \mathrm{kg}$ while organic matter content of the soil was observed to range from $0.71 \%$ to $2.50 \%$. The control soil sample had the least organic carbon $(0.41 \%)$ and nitrogen $(0.07 \%)$ contents when compared to the concentrations observed in soil samples obtained 10 meters, 20 meters and 30 meters near the telecommunication mast. In addition, the moisture content of the soil samples were $0.12 \%, 0.11 \%$ and $0.24 \%$ for soil samples obtained from 10 meters, 20 meters and 30 meters near the telecommunication mast, while the control soil sample had moisture content of $0.21 \%$ (Table 1 ).

Table 1: Physico-chemical properties of soil samples isolated soil sample found near telecommunication mast

\begin{tabular}{lcccccc}
\hline $\begin{array}{l}\text { Location } \\
\text { (Distance, m) }\end{array}$ & $\mathrm{pH}$ & $\begin{array}{c}\text { Phosphorus } \\
(\mathrm{mg} / \mathrm{kg})\end{array}$ & $\begin{array}{c}\text { Organic } \\
\text { Matter } \\
(\%)\end{array}$ & $\begin{array}{c}\text { Organic } \\
\text { Carbon } \\
(\%)\end{array}$ & $\begin{array}{c}\text { Nitrogen } \\
(\%)\end{array}$ & $\begin{array}{c}\text { Moisture } \\
\text { Content } \\
(\%)\end{array}$ \\
\hline A $(10 \mathrm{~m})$ & 6.48 & 5.96 & 1.34 & 0.78 & 0.15 & 0.12 \\
B $(20 \mathrm{~m})$ & 8.02 & 23.95 & 2.50 & 1.45 & 0.28 & 0.11 \\
C $(30 \mathrm{~m})$ & 7.80 & 13.01 & 2.18 & 1.26 & 0.25 & 0.24 \\
D (Control) & 6.24 & 2.77 & 0.71 & 0.41 & 0.07 & 0.21 \\
\hline
\end{tabular}

Control: soil samples obtained away from the telecommunication mast.

The particle sizes of the soil samples were sand, silt and clay. Silt was higher in samples collected 10 meters $(43.76 \%), 20$ meters $(41.18 \%)$ and 30 meters $(41.57 \%)$ within the vicinity of the mast while control soil sample had lowest silt of $10.71 \%$. Sand was significantly higher in control (52.82\%) while samples $14.75 \%, 36.56 \%$, 23.66\% were observed for sand samples obtained 10 meters, 20 meters and 30 meters near the telecommunication mast respectively. The highest and least particle sizes for the clay soil were observed in soil samples collected 10 meters and 30 meters near the telecommunication mast respectively (Figure 1).

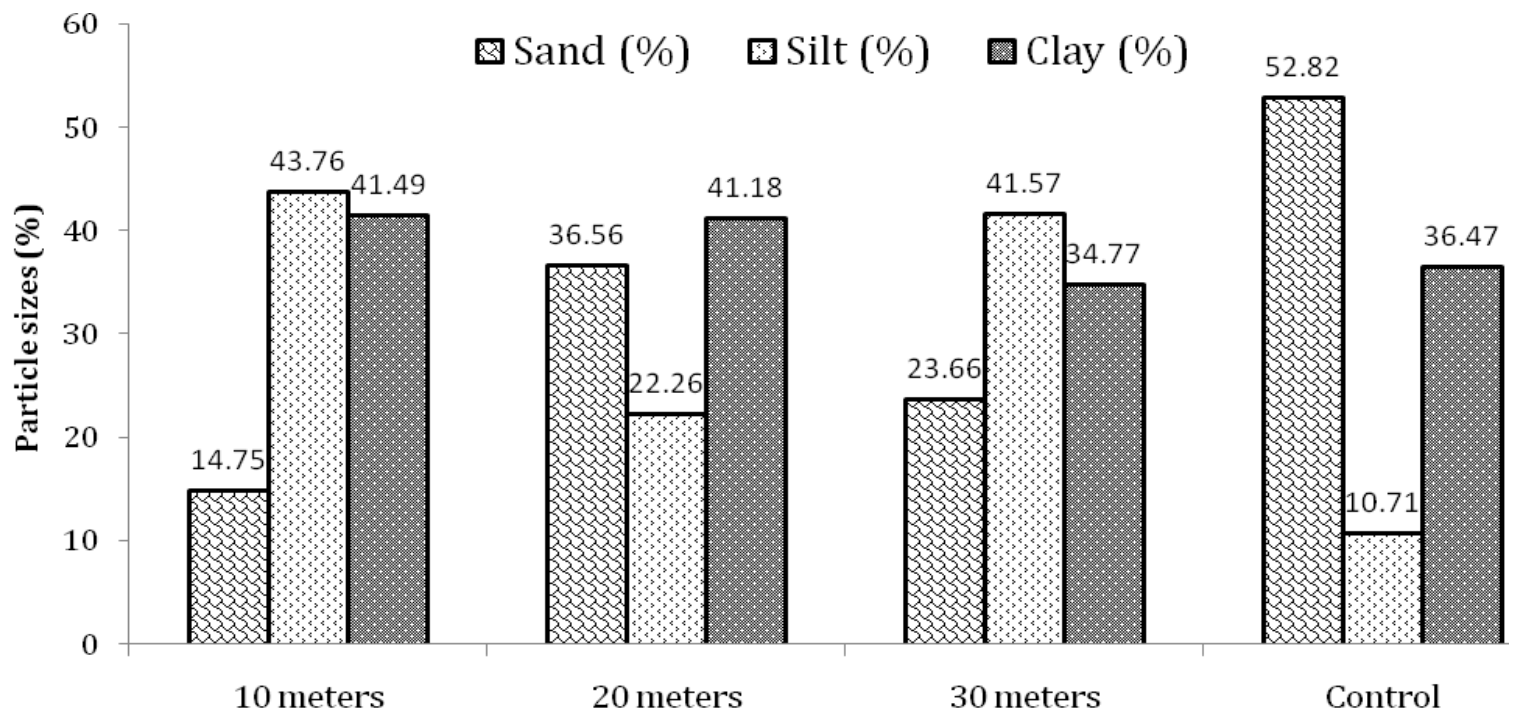

Distance (meters)

Figure 1: Soil particle sizes found near telecommunication mast

Mean Count of Non-Symbiotic Nitrogen Fixing Bacteria

The present study shows the mean count of non-symbiotic nitrogen fixing bacteria of the sampled soil (Table 2). The mean count of non-symbiotic nitrogen fixing bacteria in soil samples ranged between $1.20 \times 10^{6}$ and $3.20 \times 10^{6} \mathrm{cfu} / \mathrm{g}$. In order of occurrence, the mean count of non-symbiotic nitrogen fixing bacteria are $\mathrm{B}>\mathrm{C}>\mathrm{A}>\mathrm{D}$. There was significant difference $(P=0.0012)$ in the mean of non-symbiotic nitrogen fixing bacteria count of the different sampling points. 
Table 2: Mean Counts of Non-Symbiotic Nitrogen Fixing Bacteria

\begin{tabular}{ll}
\hline Samples (Location, $\mathrm{m})$ & Count $\left(\times 10^{6} \mathrm{cfu} / \mathrm{g}\right)$ \\
\hline A $(10 \mathrm{~m})$ & $1.40 \pm 0.23^{\mathrm{a}}$ \\
B $(20 \mathrm{~m})$ & $3.20 \pm 0.06^{\mathrm{b}}$ \\
C $(30 \mathrm{~m})$ & $1.80 \pm 0.12^{\mathrm{c}}$ \\
D (Control) & $1.20 \pm 0.20^{\mathrm{ab}}$ \\
\hline
\end{tabular}

Values are Mean \pm SD of triplicate estimation. Mean with different superscript letters are significantly different at $P<0.05$. A, B and C samples collected within the vicinity of the mast. $\mathrm{D}=$ Control (sample collected outside the vicinity of the mast), Cfu/g = colony forming unit per gram.

\section{Biochemical Identification of the Isolates}

Table 3 showed the biochemical characteristics of the isolates. A number of 14 isolates were found to belong to the species of Azomonas agilis, Azotomonas insolita, Bacillus megaterium, Bacillus mycoides, Bacillus azotoformans, Enterobacter cloacae and Klebsiella pneumoniae.

\section{Table 3: Biochemical Characterization of Non Symbiotic Nitrogen Fixing Bacteria in the Soil Samples}

\begin{tabular}{|c|c|c|c|c|c|c|c|c|c|c|c|c|c|c|c|c|c|c|}
\hline Code & Spo & Gra & Cat & Lac & Suc & Glu & Cit & Mot & Ind & Ure & MR & VP & Nit & $\mathrm{H}_{2} \mathrm{~S}$ & Gas & Oxi & Sta & Organism \\
\hline $\mathrm{A} 1$ & - & - & + & + & + & + & + & - & - & - & - & - & + & - & + & - & - & Enterobacter cloacae \\
\hline $\mathrm{A} 2$ & + & + & + & + & + & + & + & + & - & - & - & - & - & - & - & - & + & Bacillus megaterium \\
\hline A3 & - & - & + & + & + & + & + & - & - & + & - & - & + & - & - & - & - & Klebsiella pneumonia \\
\hline B1 & + & + & + & + & + & + & + & + & - & - & - & - & - & - & - & - & + & Bacillus megaterium \\
\hline B2 & - & - & + & + & + & + & + & - & - & - & - & - & + & - & + & - & - & Enterobacter cloacae \\
\hline B3 & + & + & + & - & + & - & + & - & - & + & - & + & + & - & - & + & + & Bacilluss mycoides \\
\hline B4 & - & - & + & + & + & + & + & - & - & - & - & + & + & - & - & - & - & Klebsiella pneumoniae \\
\hline $\mathrm{C} 1$ & - & - & + & - & - & - & + & + & + & + & - & - & + & - & - & + & - & Azomona agilis \\
\hline $\mathrm{C} 2$ & + & + & + & - & + & - & - & + & - & + & - & + & + & - & - & + & + & Bacillus mycoides \\
\hline $\mathrm{C} 3$ & - & - & + & + & + & + & - & - & - & - & - & - & + & + & + & - & - & Enterobacter cloacae \\
\hline $\mathrm{C} 4$ & + & + & + & - & - & + & + & + & - & + & - & - & + & - & - & - & + & Bacillus azotoformans \\
\hline $\mathrm{C} 5$ & - & - & + & + & + & + & + & + & - & - & - & + & + & - & + & - & - & Klebsiella pneumonia \\
\hline D1 & - & - & + & + & - & - & + & - & - & + & - & - & + & + & + & + & + & Azotomonas insolita \\
\hline D2 & + & + & + & + & + & - & - & + & - & + & - & + & + & - & - & + & + & Bacillus mycoides \\
\hline
\end{tabular}


Frequency of Occurrence of Non-Symbiotic Nitrogen Fixing Bacterial Species

Table 4 shows the frequency of occurrence of non-symbiotic nitrogen fixing bacterial species isolated from soil samples. The percentage distribution of the non-symbiotic nitrogen fixing bacterial species are Azomonas agilis 1(7.14\%), Azotomonas insolita 1(7.14\%), Bacillus megaterium 2(14.28\%), Bacillus mycoides $3(21.42 \%)$, Bacillus azotoformans 1(7.14\%), Enterobacter cloacae 3(21.42\%) and Klebsiella pneumonia 3(21.42\%). In addition, A, B, C and D soil samples had percentage distribution of the non-symbiotic nitrogen fixing bacterial species of $21.42 \%, 28.56 \%, \quad 35.7 \%$ and $14.28 \%$ respectively.

Table 4: Frequency of Occurrence of Non Symbiotic Nitrogen Fixing Bacterial Species in Relation to Sampling Sites

\begin{tabular}{llllll}
\hline NNFB Species & A & B & C & D & Total \\
\hline Azomonas agilis & $0(0.0)$ & $0(0.0)$ & $1(7.14)$ & $0(0.0)$ & $1(7.14)$ \\
Azotomonas insolita & $0(0.0)$ & $0(0.0)$ & $0(0.0)$ & $1(7.14)$ & $1(7.14)$ \\
Bacillus megaterium & $1(7.14)$ & $1(7.14)$ & $0(0.0)$ & $0(0.0)$ & $2(14.28)$ \\
Bacillus mycoides & $0(0.0)$ & $1(7.14)$ & $1(7.14)$ & $1(7.14)$ & $3(21.42)$ \\
Bacillus azotoformans & $0(0.0)$ & $0(0.0)$ & $1(7.14)$ & $0(0.0)$ & $1(7.14)$ \\
Enterobacter cloacae & $1(7.14)$ & $1(7.14)$ & $1(7.14)$ & $0(0.0)$ & $3(21.42)$ \\
Klebsiella pneumoniae & $1(7.14)$ & $1(7.14)$ & $1(7.14)$ & $0(0.0)$ & $3(21.42)$ \\
Total & $3(21.42)$ & $4(28.56)$ & $5(35.7)$ & $2(14.28)$ & $14(100)$ \\
\hline
\end{tabular}

NNFB Species $=$ Non-Symbiotic Nitrogen Fixing Bacterial Species. A, B and C $=$ Samples collected within the vicinity of the mast. $D$ = Sample collected outside the vicinity of the mast. \% Occurrence of NNFB species in parenthesis, \% Frequency of occurrence $=($ Number of NNFB species /Total number of NNFB species) $\times 100$

\section{DISCUSSION}

Soil is a complex matter and comprises minerals, soil organic matter, water, and air. These fractions greatly influence soil texture, structure, and porosity. Therefore, soil physicochemical properties have a great influence on the soil quality. Similarly, anthropogenic activities have been known to have significant influence on soil quality as reported by Li et al. (2017). This study focused on the characteristics of soil samples collected within the vicinity of telecommunication mast. Physicochemical parameters of soil $\mathrm{pH}$, phosphorus, organic carbon, nitrogen, moisture content and soil particle sizes were observed in this research work.

Soil $\mathrm{pH}$ is an important physicochemical factor controlling the growth and metabolic activities of soil non-symbiotic nitrogen fixing bacteria (Merlo and Susana, 2014). The $\mathrm{pH}$ range of samples within the vicinity of the mast ranged from 6.48 to 8.02 . This $\mathrm{pH}$ range satisfied $\mathrm{pH}$ with which the non-symbiotic nitrogen fixing bacteria can grow. Rousk et al. (2010) showed strong influence of $\mathrm{pH}$ on the abundance and composition of bacterial communities in the soil. However, Ding et al. (2005) reported the neutral $\mathrm{pH}$ to be the optimal condition for non symbiotic nitrogen fixation.

Organic carbon is another factor regulating the activity of non-symbiotic nitrogen fixing bacteria.
The organic carbon content observed in samples collected 20 meters and 30 meters near the telecommunication mast were higher compared to the control sample. Soil organic carbon is considered to be the critical indicator for health and quality of the soil (Nelson and Sommers, 1982) and could be the reason for the higher counts and species distribution recorded in these samples. Hoffman-Findeklee et al. (2000) reported that non-symbiotic nitrogen fixers rely on extracellular organic carbon for respiration and carbon may be more limiting than other nutrient availability.

Phosphorus is essential for plant growth and development and required for metabolic activities of non-symbiotic nitrogen fixers and serves as one of the drivers of nitrogen fixation rate. High content of phosphorus was recorded in samples within the vicinity of the mast compared to control sample and the lowest count and species distribution observed in control sample could be attributed to low phosphorus content, as low phosphorus availability has been reported to limit non symbiotic nitrogen fixers in several environments (Reed et al., 2011). However, higher phosphorus recorded in samples within the vicinity of the mast could be attributed to the use of phosphorus containing fertilizers such as NPK and other nitrogen rich fertilizers by farmers for plant cultivation. www.ujmr.umyu.edu.ng 
Nitrogen $(\mathrm{N})$ and phosphorous $(\mathrm{P})$ ranged from 0.07 to $0.28 \%$, and 2.77 to $23.95 \mathrm{mg} / \mathrm{kg}$ respectively. This aligns with the findings of Benton (1999) and Fomenky et al. (2018). This explains the application of fertilizers by the inhabitants. Sandip et al. (2016) in a similar study on physicochemical properties of soils found them to range from $100-350(\mathrm{mg} / \mathrm{kg})$ and $33-84(\mathrm{mg} / \mathrm{kg})$ respectively. The values were significantly lower than those of Sandip et al. (2016). The nitrogen content of the soil samples within the vicinity of the mast was higher than that of the control. This could affect the nonsymbiotic nitrogen fixers in the soil. Higher counts of nitrogen fixers are recorded in samples with higher percentage nitrogen and can be due to the fact that nitrogen was one of the critical indicators for the health and quality of soil (Nelson and Sommers, 1982; Wick et al., 2012). The amount of percentage nitrogen recorded in samples within the vicinity of the mast could be attributed to the capacity of non-symbiotic nitrogen fixing bacteria in transforming atmospheric nitrogen into fixed nitrogen in the soil and this can be attributed to the favorable conditions like carbon, moisture, organic matter, and phosphorus content that were lacking in control sample. It is very likely that exposure to electromagnetic radiation from telecommunication mast is able to induce positive changes that promote the beneficial conditions for the growth of non-symbiotic nitrogen fixing bacteria as cellular phone associated mast radiation has been reported as one of the primary factors influencing the way in which microbes interact with ecosystems (Iheme et al., 2016).

Soil organic matter is a valuable property of soil. If the soil is poor in organic matter, then it enhances the process of soil erosion ( $\mathrm{Ku}$ and Sangita, 2015). If the soil organic matter is present in soil, then this soil is useful for the agricultural practices. Organic matter may be added in the soil in the form of animal manures, compost, etc. The presence of the higher content of organic matter as observed in the present study can be another possible reason for lowering of the $\mathrm{pH}$. Soil organic matter content has decreased from surface to subsoil due to leaching (Kekane et al., 2015).

\section{REFERENCES}

Adebayo, E.A., Adeeyo, A.O., Ayandele, A.A. and Omomowo, I.O. (2014). Effect of Radiofrequency Radiation from
The mean count of non-symbiotic nitrogen fixing bacteria in soil samples ranged between $1.20 \times$ 106 and $3.20 \times 10^{6} \mathrm{cfu} / \mathrm{g}$. Sample $B$ had the highest count of $3.2 \times 10^{6} \mathrm{cfu} / \mathrm{g}$ while lowest count was observed in sample $D$ with $1.2 \mathrm{x}$ $10^{6} \mathrm{cfu} / \mathrm{g}$. However, no significant difference existed among the samples at $P(<0.05)$. The highest count recorded in samples within the vicinity of the mast could be due higher values of physicochemical parameters which were reported to influence bacterial growth. Physicochemical parameters nitrogen, phosphorus, organic carbon, organic matter were higher in samples $A$, $B$ and C (Table 1). Nelson and Sommers (1982) reported that physicochemical parameters typically nitrogen was one of the critical indicator for health and quality of soil. Therefore, the higher count could be attributed to the higher nitrogen content in the soil.

A number of non symbiotic nitrogen fixing bacteria were isolated and identified and were the species of Azomonas agilis, Azotomonas insolita, Bacillus megaterium, Bacillus mycoides, Bacillus azotoformans, Enterobacter cloacae and Klebsiella pneumoniae with the occurrence of 1(7.14\%), 1(7.14\%), 2 (14.28 \%), 3(21.42\%), $1(7.14 \%), 3(21.42 \%)$ and $3(21.42 \%)$ respectively. These bacteria were known to be widely distributed in the soil where they reduce atmospheric nitrogen in soil (Onyeze et al., 2013). In agreement with the current study, Rifat et al. (2010) and Ibrahim et al. (2014) in their separate study reported the isolation and identification of these species from agricultural soil.

\section{CONCLUSION}

In the present study we found that there was slight variation in the physicochemical parameters of the soil samples collected from varying points within the vicinity of the mast compared to the control sample. In addition, the present study observed that soil samples collected within the vicinity of telecommunication mast contain what it needed for all forms of life like microbes to survive and would not negatively affect the non-symbiotic nitrogen fixers in the soil, regardless of the radiation from the telecommunication mast.

Telecommunication Based Stations on Microbial Diversity and Antibiotic Resistance. Journal of Applied Science www.ujmr.umyu.edu.ng 
and Environmental Management, 18(4): 669-674.

Ahmed, I., Istivan, T., Cosic, I and Pirogova, E (2013). Irradiation of E. coli by Extremely Low Frequency (ELF) Pulsed Electromagnetic Field: Evaluation of Bacterial Survival. Journal of Electromagnetic Waves, 29(1):26-37.

Balmori, A. (2016). Radiotelemetry and Wildlife: Highlighting a Gap in the Knowledge on Radiofrequency Radiation Effects. Science of the Total Environment, 543 (pt A), 662-669.

Belbe, M.G. and Tofana, M.(2010).Effects of lonizing Radiation on Microbiological Contaminants of Food. Bulletin UASVM Agriculture, 67(2) Pp.179-181

Belyaev, I. (2005). Non-thermal Biological Effects of Microwaves. Microwave Review, 11: 13-29

Belyaev, I. (2011). Toxicity and SOS-response to ELF Magnetic Fields and Nalidixic Acid in E. coli cells. Mutation Research, 722: 5661.

Benton, J.J. (1999). Soil Analysis Handbook of Reference Methods. Soil and Plant Analysis Council.Inc. Soil Science. 2nd ed. CRC Press.

Cheesbrough M. (2006). Medical Laboratory Practice inTropical countries. Part 2, 2nd ed. United Kingdom: Cambridge University Press; Page 157-200.

Ding, Y., Wang, J., Liu, Y. and Chen, S. (2005). Isolation and Identification of Nitrogen Fixing Bacilli from Plant Rhizospheres in Beijing Region. Journal of Applied Microbiology, 99: 1271 - 1281

Emmyrafedziawati, A.K.R. and Stella, M. (2018). Identification of Free Living Nitrogen Fixing Bacteria Isolated From EFB Compost, Molecular Detection of $\mathrm{NifH}$ Gene and Measurement of Nitrogenase Activity. Journal of Tropical Agriculture and Food Science, 46(1): 39-46.

Eno, J.U., Ibia, T.O., Ogunwale, J.A., Ano, A.O. and Esu I.E. (2009). Manual of Soil, Plant and Water Analysis. Sibon Book Publishers Lagos .Pp 6-7.

Fomenky, N.N., Tening, A.S., Chuyong, B.G., Mbene, K., Asongwe, G.A. and Vivian, B.C. (2018). Selected Physicochemical Properties and Quality of Soils Around Some Rivers of Cameroon. Journal of Soil Science and Environmental Management, 9(5): 68-80.
Gee, W.G. and Or, D. (2002). Particle Size Analysis. In: Method of Soil Analysis. Book series 5. Part 4. Soil Science Society of America. Pp 255-293

Habtamu A (2011) Land Use/Land Covers Change and Impacts of Jatropha on Soil Fertility: The Case of Mieso and Bati Districts, Ethiopia (M.Sc. Thesis) Haramaya University, Ethiopia. Pp. 11-30.

Hoffman-Findeklee, C., Gadkari, D. and Meyer, O. (2000). Superoxide-dependent Nitrogen Fixation. In Nitrogen Fixation: From Molecules to Crop Productivity. pp. 23-30.

Ibrahim, U.B., Ijah, U.J.J., Riskuwa, M.L. and Manga, S.B. (2014).Microbial and Heavy Metals Qualities of Agricultural Soils of Tsafe Local Government Area in Zamfara State-Nigeria. Journal of Zoological and Bioscience Research, 1(2): 18-30.

Iheme, C.I., Nwaougikpe, R.N., Nwaogu, L.A., Ujowundu, C.O., Ukairo, D.I. and Orji, C.E. (2016). Effect of Electromagnetic Radiation (EMR) on Some Soil Physicochemical Parameters, Catalase and Dehydrogenase Activities. IOSR Journal of Environmental Science Toxicology and Food Technology (IOSRJESTFT), 10(1): 25-34.

Kekane, S.S., Chavan, R.P., Shinde, D.N., Patil, C.L. and Sagar, S.S. (2015). A Review on Physico-chemical Properties of Soil. International Journal of Chemical Studies, 3(4): 29-32.

Ku S.T, and Sangita, I. (2015). A Review on Role of Physico-Chemical Properties in Soil Quality. Chemical Science Review Letters, 4(13):57-66.

Li, X., Wang, Y. and Lu, X. (2017). Long term agricultural activity affects anthropogenic soil on Chinese loess plateu. Journal of Arid Land, 9: 678-687.

Merlo, C. and Susana, G. (2014). Environmental Factors Associated with Heterotrophic Nitrogen Fixing Bacteria in Water, Sediment and Riparian Soil of Suquia River. Limnologica, 48: 71-79.

Nelson, D.W. and Sommers, L.E. (1982). Total Carbon, Organic Carbon, and Organic Matter. In: Page, A. L. and Keeney, D. R. (eds), Methods of Soil Analysis Part 2. Madison, WI. American Society of Agronomy. 539-579.

Onyeze, R., Onah, G. and Cecilia, I. (2013). Isolation and characterization of nitrogen 
fixing bacteria in the soil. International Journal of Life Sciences, 2(3): 438-445

Reed, S.C., Cleverlend, C.C and Townsend, A.R (2011). Functional Ecology of Free Living Nitrogen Fixation: A Contemporary Perspective. Annual Review of Ecology Evol ution and Systematics. 42.489-512.

Rifat, H., Safdar, A., Ummay, A., Rabia, K. and Iftikhar, A. (2010). Soil Beneficial Bacteria and Their Role in Plant Growth Promotion: A Review. Annals of Microbiology, 60(4): 579-598.

Rousk, J., Bengston, P. and Stemgren, E. (2010). Archael Abundance Across a pH Gradient in an Arable Soil and its Relationship to Bacterial and Fungal Growth Rates. Applied and Environmental Microbiology, 78(16): 5906-5911.

Saleh, H.S., Alharbi, A.S., Faden , A.A and Wainwright ,M. (2018). Evaluation of the Effect of High Frequency Electromagnetic Field on Growth and Antibiotic Sensitivity of Bacteria. Saudi Journal of Biological science, 25(I):105-110

Sandip, S.B., Vaneet, K., Navdeep, S., Vasudha, S., Jaswinder, S., Jatinder, K.K., Avinash, KN (2016). Physico-chemical Properties and Heavy Metal Contents of Soils and
Kharif crops of Punjab, India. Proceedia Environmental Science. 3:801-808.

Sienkiewicz, Z., Calderon,C., Kerry, A.B., Addison, D., Gavarrd, A. Louise, L. and Maslanyj,M.(2017). Are Exposure to Multiple Frequencies the Key to Future Radiofrequency Research?. Frontiers in Public Health. 5:328

Tai, X.S., Mao, W.L., Liu, G.X., Chen, T., Zhang, W., Wu, X.K., Long, H.Z., Zhang, B.G. and Zhang, Y. (2013). High Diversity of Nitrogen-fixing Bacteria in the Upper Reaches of the Heihe River, Northwestern China. Biogeosciences, 10: 5589-5600.

Vummiti, D. (2015). Determination of Available Nutrients in Soil using the Agilent 4200 MP-AES. Agilent Technology Inc pp 2-3

Wick K, Heumesser C. and Schmidt, E. (2012). Groundwater Nitrate Contamination: Factors and Indicators. Journal of Environmental Management, 111(3):178186.

Yari, S., Asadi, A.F., Jarrahi, A.M and Mohammadi, N.M. (2019). Biological Effects of Electromagnetic Waves with Emphasis on Radio and Microwaves. An Environmental Carcinogen, 2(1)35-41. 